\section{CONTENTS OF THE SPLENIC VEIN.}

To the Editor.-Sir : On the re-opening of the controversy " on the anatomy and physiology of the spleen," by the publication of Mr. Stevens's paper in The LANCET of January 14th (page 584), allow me to notice one grand "flaw" in that gentleman's demonstration, \&c. I mean the absence of any analysis, either sensual or chemical, or of any proof whatever that the splenic vein contains arterial blood. I believe that I was the first to call attention to the fact that the splenic vein (so called) did not contain venous blood; I now equally object that it does not contain arterial blood, which objection, if well founded (as, from mere sensual analysis, I believe it to be), is at once fatal to Mr. Stevens's theory, and may save the shedding of some ink. I am, Sir, your obedient servant,

Kingsland-road, J an. 15, 1843.

Francis Eagle.

\section{FORTITUDE OF THE MIND DURING OPERATIONS.}

\section{To the Editor of The Lancet.}

SIR,-That the fortitude which is necessary to enable a patient to bear a surgical operation without making any exclamations of suffering can be produced through the mind only, without having recourse either to mesmerism or opium, the following instances, among many others that I could adduce, sufficiently testify.

When the late gallant officer, Sir Thos. B. Thompson, Bart., lost his leg in action, it is well known that he was singing during the time the amputation was being performed. A monument to the brave admiral is erected in the burial-ground of this institution, and in the same ground is one to a seaman of the Leviathan, who was wounded in the battle of Trafalgar, and of whom the epitaph states that "In this he shares but in common with many others, the praise and the glory of having died in defence of his country; but he farther signalised himself by a display of fortitude which is not surpassed in the records of naval intrepidity. The severity of his wound required the amputation of his left arm." Some part of the epitaph is here worn away by time, but it goes on to state that "while the amputation was performing he was exultingly singing the patriotic song of "Rule Britannia." Another seaman in this hospital, who was undergoing amputation of his leg without a murmur, jocosely told the surgeon, "Avast a little till I take a pinch of snuff," coolly took the box out of his waistcoat-pocket, and after having ceremoniously offered a pinch to the assistant-surgeon, took one himself, and the operation was finished without his having uttered a moan! In neither of these cases was there any mesmerism, and if ever I have wanted to tranquillise a man who was about to undergo a painful operation, I have done it by working upon his mind through his ears (not by waving my hand before his eyes), and have over and over again succeeded in creating in my patients a fortitude and resolution under which they have never murmured during the operation. I cannot help thinking that this is the only way in which such an effect can be produced, and from this you may infer what my opinion is of mesmerism. I am, Sir, your most obedient servant,

Inspector of Hospitals and Fleets. Greenwich Hospital, Jan. 9, 1843.

\section{STATISTICS OF CARCINOMA AND OPERATIONS FOR ITS CURE, \&c.}

During the five years from 1836 to 1840 inclusive, there were performed at the Hôtel Dieu, 95 operations for the excision of tumours in the female breast, and 29 operations for removal of testicles. Of the subjects of operation on the breast, 75 recovered so as to be discharged from the hospital ;* and 20 , or 1 in $4 \frac{8}{4}$ of the whole, died. Of the subjects of castration, 24 were subsequently discharged; and 5, or 1 in $4 \frac{1}{4}$ of the entire number, died.

Organic alteration of the mammary gland is certainly much more fiequent than degenerescence of the testicle; but the above com. parative view must not be considered as indicating the relative frequency of eancer in the different sexes. From the more frequent state of excitement and liability to disease into which the female generative system is brought, by menstruation, the pregnant and puerperal states, \&cc., various tbrous, fatty, and other tumours originate in the mammæ, not involving their glands, and which the patients readily suffer to be removed by excision. On the other hand, castration is never resorted to until the cancerous nature of the degenerescence in the testicle is decided. Of the above 20 female patients who died in the hospital, none succumbed in the first five days after the operation; but 4 between the 5 th and the 10th days; 7 between the 10th and 20th ; 4 between the 20th and 30 th, and 5 between the first and second months after the operation. Of the 5 patients who died after casiration, death took place in 3 instances during the first 6 days ; in 1 on the 9th day; and in 1 two months after

* The term discharged cured, would not be absolutely correct, as the patients operated on for mammary cancer frequently reentered the hospital in consequence of a return of the disease. 